\title{
Pathophysiology of diabetes mellitus and its complications: Metabolic events and control
}

\author{
Franklyn O. Ohiagu ${ }^{1}$, Paul C. Chikezie ${ }^{1, *}$, Chinwendu M. Chikezie ${ }^{2}$
}

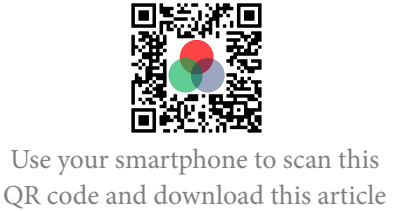

${ }^{1}$ Department of Biochemistry, Imo State University, Owerri, Nigeria

${ }^{2}$ Department of Biochemistry, Federal University of Technology, Owerri, Nigeria

\section{Correspondence}

Paul C. Chikezie, Department of Biochemistry, Imo State University, Owerri, Nigeria

Email: p_chikezie@yahoo.com

\section{History}

- Received: Feb 06, 2021

- Accepted: Mar 28, 2021

- Published: Mar 31, 2021

DOI : 10.15419/bmrat.v8i3.663

\section{Check for updates}

\section{Copyright}

(c) Biomedpress. This is an openaccess article distributed under the terms of the Creative Commons Attribution 4.0 International license.

\begin{abstract}
Background: Diabetes mellitus (DM) is a metabolic disorder that is characterized by hyperglycemia and glucose intolerance, which is associated with impaired insulin secretion, peripheral sensitivity and eventual $\beta$-cell dysfunction. This review aimed to summarize the major metabolic pathways leading to both microvascular and macrovascular complications in DM, with an emphasis on the enzymes involved and potential inhibition of the enzymes facilitating these processes as a measure of diabetic control. Methods: Data for this review were sourced online from scientific search engines, including Google Scholar, Scopus, EMBASE, PubMed, ResearchGate, Mendeley, Medline and SpringerLink, using keywords such as 'diabetic complications', 'hyperglycemiainduced diabetic mechanisms', 'diabetic enzymes', and 'diabetic enzyme inhibitors'. A total number of 109 references published online between 1990 and 2020 were generated and cited in this review. Results: The most scourging and dilapidating effects of DM, as well as its associated vascular complications, are classified into four categories, viz:: nephropathy, retinopathy, neuropathy, and cardiovascular disease. Hyperglycemia, which is associated with uncontrolled DM, elicits abnormal metabolism such that the enzymes involved in metabolic events leading to diabetic complications are expressed and amplified. The disorders associated with DM are linked to various metabolic pathways facilitated by enzymatic activities of the polyol pathway, hexosamine biosynthetic pathway, and glucose autoxidation. Also, the disorders are linked to increased synthesis of advanced glycation end-products (AGEs), hexokinase-2 driven glycolytic overload, as well as increased activities of cyclooxygenase (COX), lipoxygenase (LOX) and pyruvate kinase (PKC) enzymes. The inhibition of the enzymes involved in these pathways could serve to mitigate and arrest diabetic complications. Conclusion: Thus, suitable inhibitors for enzymes involved in DM metabolic events could serve as panaceas against DM complications, possibly adding to the growing list of new and more efficacious antidiabetic drugs.
\end{abstract}

Key words: Diabetes mellitus, diabetic complications, enzyme, hyperglycemia, inhibitor

\section{INTRODUCTION}

Diabetes mellitus (DM) is a metabolic disorder that is characterized by hyperglycemia and glucose intolerance. It is known to be associated with impaired insulin secretion and peripheral sensitivity, as well as eventual $\beta$-cell dysfunction ${ }^{1}$. DM is one of the oldest diseases worldwide ${ }^{2}$. The International Diabetes Federation report of 2017 suggested that 451 million adults globally had diabetes in 2017, and 693 million individuals are expected to suffer from DM by $2045^{3}$. The World Health Organization (WHO) also estimates that more than $19 \%$ of the world's total adult population will suffer from DM by the year $2030^{4}$. DM has been a problem of great concern over the years due to its high incidence and mortality rates, as well as its high management and treatment costs ${ }^{3}$. DM disorders are more rampant in developing nations, with more than half of the total cases undiagnosed ${ }^{1}$.
DM is classified into type 1 and type 2. However, DM can also occur during pregnancy- a type known as gestational DM. Other circumstances- such as insulin receptor impairment, pancreatic exocrine disorder, genetic disorders, and endocrinopathies- can provoke $\mathrm{DM}^{2}$. Clinically, type $1 \mathrm{DM}$ presents as hyperglycemia as a result of acute or chronic insulin deficiency in plasma ${ }^{5}$. In type $2 \mathrm{DM}$, the $\beta$-cells within the islets of Langerhans of the pancreas are hypersensitive to glucose in plasma, thereby eliciting the secretion of higher than normal insulin levels in the systemic circulation. The evidence of hyperinsulinemia is an attempt to counterbalance hyperglycemia, which further deteriorates and impairs $\beta$-cell function ${ }^{6,7}$. Chronic hyperglycemia is accompanied by high mortality and morbidity due to its concomitant microvascular complications, such as nephropathy, neuropathy and retinopathy, as well as macrovascular complications which include cardiovascular diseases leading to myocardial infarction and stroke $\mathrm{k}^{2,8}$. 
Hyperglycemia, which is associated with uncontrolled DM, elicits abnormal metabolism such that the enzymes involved in the metabolic events leading to diabetic complications are expressed and amplified $^{8}$. Therefore, such enzymes can serve as therapeutic targets for the treatment of $\mathrm{DM}^{9}$. This review summarizes the major metabolic pathways leading to both microvascular and macrovascular complications in DM, and highlights the potential inhibition of the enzymes facilitating these processes as an instrument of diabetic control.

\section{METHODS}

\section{Evidence acquisition}

Data summarized in this review were sourced online from scientific search engines, including Google Scholar, Scopus, EMBASE, PubMed, ResearchGate, Mendeley, Medline and SpringerLink, using keywords such as 'diabetic complications', 'hyperglycemia-induced diabetic mechanisms', 'diabetic enzymes', and 'diabetic enzyme inhibitors'. A total number of 109 references published online between 1990 and 2020 were evaluated and cited in this review.

\section{RESULTS}

\section{Diabetic complications}

A significant number of complications accompany DM. However, the most dilapidating effects of DM and its associated vascular complications are classified into four categories, viz.: nephropathy, retinopathy, neuropathy, and cardiovascular disease ${ }^{2}$.

\section{Nephropathy}

Diabetic nephropathy is the main initiator of endstage renal failure in the Western regions of the world $^{10}$. Poor glycemic control is a risk factor for the occurrence of diabetic nephropathy ${ }^{11}$. Clinically, nephropathy is accompanied by an emergence of proteinuria with a concomitant reduction in glomerular filtration rate, leading to fatal uremia if not treated. Kidney disease is also characterized by macrovascular complications, including strokes and heart attacks ${ }^{2}$. According to Amico and Klein ${ }^{12}$, a rise in blood pressure is also associated with the onset of nephropathy.

\section{Retinopathy}

Diabetic retinopathy is the major cause of blindness in individuals between the ages of $20-74$ years ${ }^{13,14}$ since it initiates an array of lesions in the retina. It is typically characterized by vascular permeability changes, capillary degeneration, capillary microaneurysms, and abnormal production of blood vessels.
Color vision deficiency is also another common effect of retinopathy ${ }^{13}$.

According to Forbes and Cooper ${ }^{2}$, hyperglycemia induces alteration in the blood-retinal barrier and its vascular permeability at the early stages of diabetic retinopathy. However, the visual disorders that occur at this stage are not noticeable to most sufferers.

\section{Neuropathy}

Diabetic neuropathy involves the destruction of the nerves and is one of the most prevalent diabetic complications. More than half of diabetic patients suffer from neuropathy ${ }^{15,16}$. Diabetic neuropathy is the main risk factor for wound healing impairment commonly encountered in $\mathrm{DM}^{2}$. According to Obrosova et al. ${ }^{17}$, advanced diabetic neuropathy, as a result of impairment of the nerve fiber, leads to a total decline in sensory perception. Other complications associated with diabetic neuropathy include erectile dysfunction, cardiovascular dysfunction, paresthesia, hyperalgesia and allodynia ${ }^{2,17}$.

\section{Cardiovascular disease}

There is a high prevalence of cardiovascular disease among individuals suffering from $\mathrm{DM}^{2}$. Cardiovascular disease is responsible for more than half of the total number of deaths recorded as a result of diabetic complications ${ }^{18}$. The risk of myocardial infarction among diabetic patients was equivalent to normal human subjects with a previous history of myocardial infarction ${ }^{19}$. The major disorders associated with cardiovascular disease among diabetic individuals include premature atherosclerosis, accompanied by myocardial infarction, stroke, and cardiac dysfunction $^{2}$.

Furthermore, cardiovascular disease in type $1 \mathrm{DM}$ occurs sequentially to obstruction in kidney function $^{20,21}$. In the same manner, poor glycemic control and kidney disease can provoke cardiovascular disease in type $2 \mathrm{DM}^{22}$.

\section{Metabolic pathways leading to complica- tions in DM}

Certain metabolic processes which are activated by hyperglycemia have been demonstrated to induce the complications associated with DM. These mechanisms, including enzymes and their intermediates, as well as inhibitors of these enzymes, are discussed below. 


\section{Protein kinase C (PKC) activation}

The PKC family is comprised of more than eleven isoforms of serine-threonine kinases which play a major role in the modulation of endothelial cell permeability, activation of cell proliferation, and vascular growth $^{23}$. PKC $\beta$ is the core target in the escalation of diabetic disorders ${ }^{24,25}$. The activation of PKC $\beta$ in diabetic animals and vascular cells is initiated by hyperglycemia ${ }^{24,25}$. An increase in blood glucose levels is accompanied by PKC activation in various tissues, including heart, retina, and renal glomeruli, which eventually exacerbates diabetic complications in both humans and animal models (Figure 1) ${ }^{26-28}$. High blood glucose levels directly activate the polyol pathway, whereas PKC associated with the polyol pathway is known to induce diabetic complications. Accordingly, the polyol pathway is linked with the generation of oxidative stress, leading to the emergence of diabetic complications as observed clinically (Figure 2) ${ }^{29-31}$. Additionally, continuous PKC activation stimulates different growth factors, including transforming growth factor $\beta$, platelet-derived growth factor, and vascular endothelial growth factor $^{32,33}$.

The study carried out by Thomas et al., ${ }^{34}$ on the protein kinase inhibitory activity of crude methanol extract of Bocconia frutescens using hyphae formation inhibition assay against Streptomyces $85 E$ at 20 $\mu \mathrm{g} /$ disk concentration, yielded positive results. The alkaloids- namely chelerythrine and berberine- were reported in this plant extract and were responsible for the protein kinase inhibitory effects of this plant ${ }^{34}$.

\section{The increased flow of the polyol pathway}

The polyol pathway flux consists of two key enzymes: aldose reductase (AR) and sorbitol dehydrogenase (SD). In the polyol pathway, glucose is reduced to sorbitol (alcohol) by AR, followed by the oxidation of sorbitol to fructose by SD. Both the AR- and the SD-catalyzed steps involve using nicotinic acid adenine dinucleotide phosphate (NADPH) (Figure 2) ${ }^{35}$. The rate of the polyol pathway is dependent on the AR step; AR possesses low glucose affinity $(\mathrm{Km}>$ $100 \mathrm{mM}$ ) in nondiabetic individuals with normal glucose levels. Indeed, glucose metabolism via the polyol pathway involves the utilization of a very small amount of glucose ${ }^{36}$.

Under hyperglycemic conditions, AR is activated by rising intracellular glucose levels. The AR reaction eventually leads to the generation of springy polar sorbitol, which permeates the cell membranes, resulting in the distortions of cellular structure and activity, osmotic cell swelling, and reduction in ATPase function $^{23}$. The oxidation of sorbitol activates PKC to fructose- a process catalyzed by $\mathrm{SD}$ - via a rise in $\mathrm{NADH} / \mathrm{NAD}^{+}$ratio $^{37}$. Oxidative stress is generated in the polyol pathway via redox imbalance ${ }^{38,39}$. Thus, the polyol pathway is associated with a vast array of diabetic complications (Figure 2).

Emodin, aurantio-obtusin and chryso-obtusin-2-O$\beta$-D-glucoside, isolated from the ethyl acetate soluble extract of Cassia tora seeds elicited inhibitory effects on $\mathrm{AR}$, with corresponding $\mathrm{IC}_{50}$ of 15.9, 13.6 and $8.8 \mu \mathrm{mol} / \mathrm{L}$, respectively, against $\mathrm{AR}$ in rat lens ${ }^{40}$. Out of six phytocompounds isolated from Glycyrrhizae radix roots, only isoliquiritigenin gave a strong inhibitory effect on $\mathrm{AR}$ as well as blocking the buildup of sorbitol in tissues of diabetic rats ${ }^{41}$. According to the inhibitory study carried out by Jung et al., ${ }^{42}$ twelve phenolic compounds were isolated from Belamcanda chinensis rhizomes, among which tectorigenin and tectoridin gave the most potent and highest inhibitory effect $\left(\mathrm{IC}_{50} \mathrm{~s}\right.$ $=1.12$ and $1.08 \mu \mathrm{mol} / \mathrm{L}$, respectively). Phenolic compounds blocked the accumulation of sorbitol in streptozotocin-induced diabetic rats within a period of 10 days at a dose of $100 \mathrm{mg} / \mathrm{kg}^{42}$. The AR inhibitory effect of luteolin isolated from Chrysanthemum boreale at $\mathrm{IC}_{50}$ was $0.5 \mu \mathrm{mol} / \mathrm{L}^{43}$. The phytocompound, 3, 5-dicaffeoylquinic acid (chlorogenic acid derivative), from Ipomoea batatas roots produced a substantial inhibitory effect on AR from rat lens ${ }^{44}$. Other phytocompounds with AR inhibitory effect include isoaffinetin from Manilkara indica ${ }^{45}$, rhetsinine from hot water extract of Euodia rutaecarpa ${ }^{46}$, matteuorienate A and B from Matteuccia orientalis rhizome $^{47}$, puerariafuran from Pueraria lobata ${ }^{48}$, and hypolaetin from Sideritis brevibracteata $n$-butanol extract $^{49}$.

\section{The increased flow of the hexosamine biosynthetic pathway}

The contribution of the hexosamine biosynthetic pathway in the emergence of insulin resistance, as well as diabetic vascular complications, has been reported $^{1,51}$. This pathway involves the conversion of fructose-6-phosphate (fruc-6-P) to glucosamine6-phosphate (glucN-6-P) using glutamine as the amino donor. The conversion of fruc-6-P to glucN-6-P is catalyzed by glutamine: fructose-6phosphate-amidotransferase (GFAT), which is the rate-limiting enzyme of the hexosamine biosynthetic pathway. GlucN-6-P is instantly channeled towards the synthesis of uridine-5-diphosphate-Nacetylglucosamine (UDP- $N$-acetylglucosamine). The 


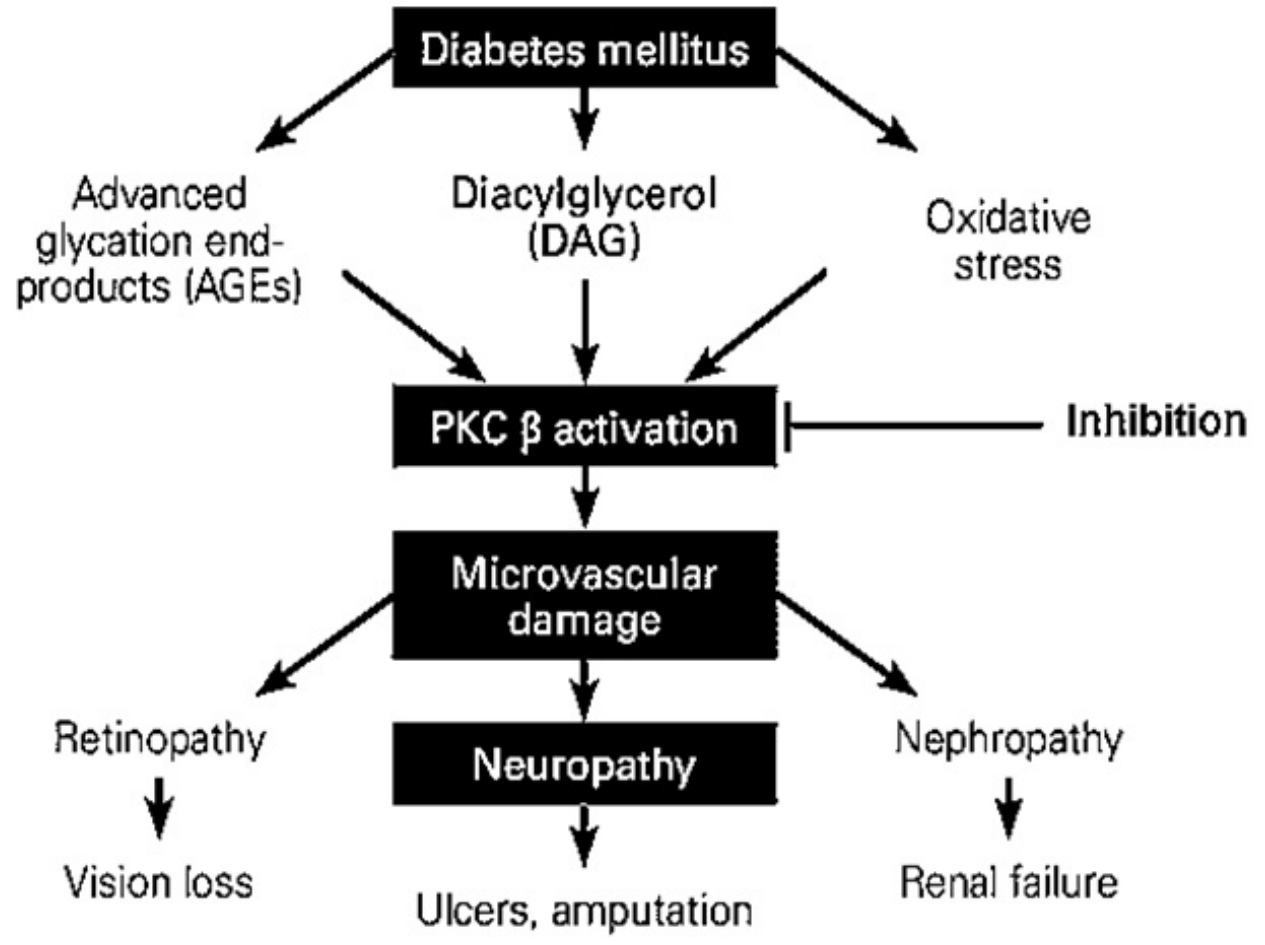

Figure 1: Diabetic complications arising from the activation of PKC $\beta^{29-33}$.

UDP-N-acetylglucosamine is the precursor for the biosynthesis of the necessary amino sugars required for the generation of glycoproteins, proteoglycans, glycosaminoglycans, and glycolipids ${ }^{51-53}$. Extremely high blood sugar levels induce the development of diabetic complications through the elevation of fruc6-P concentration, which flows into the hexosamine biosynthetic pathway ${ }^{54,55}$. However, increased blood glucose concentration induces metabolic pathways that eventually promote the release of cytokines such as TGF- $\beta$, ICAM- 1 , VCAM-1, TNF- $\alpha$, CTGF and PAI-1, involved in various diabetic complications (Figure 3) ${ }^{56,57}$. For instance, transforming growth factor- $\beta 1$ (TGF- $\beta 1$ ) plays a significant role in diabetic nephropathy ${ }^{51}$. Upon cellular glucose uptake, relatively larger glucose concentrations are catabolized and channeled towards glycogenesis, glycolysis, and pentose phosphate metabolism. Moreover, about 2$3 \%$ of glucose molecules are channeled into the hexosamine biosynthetic pathway ${ }^{57,58}$.

Nevertheless, the inhibition of the rate-limiting enzyme, GFAT, of the hexosamine biosynthetic pathway blocks the hyperglycemic-induced transcription of the cytokines, thereby preventing the various diabetic complications which might possibly arise from the pathway ${ }^{51,53,54,59}$.

The photo components present in fenugreek extracts possess an inhibitory effect against the ratelimiting enzyme pathway of the hexosamine biosynthetic pathway ${ }^{60}$. Diabetic mice fed with fenugreekcontaining food showed an inhibited GFAT activity, whereas those given starch diets without fenugreek exhibited an increase in GFAT activity compared with the control group ${ }^{60}$. The anti-hyperglycemic potency of Euphorbia thymifolia via the inhibition of GFAT has also been reported. The following phytocomponents from $E$. thymifolia, namely $\beta$-amyrin, taraxerol, 1-Ogalloyl- $\beta$-D-glucose, corilagin, cosmosiin, quercetin3 -galactoside, and quercitrin, all exhibited inhibitory efficacy against GFAT with an absolute binding energy of $>8 \mathrm{kcal} / \mathrm{mol}^{61}$.

\section{Increased synthesis of advanced glycation end-products ( AGEs)}

AGEs are yellowish-brown fluorescent substances. They are generated via the Maillard reaction. Specifically, they are produced via the non-enzymatic reaction between reducing sugars (e.g., glucose) and the amino group of proteins, leading to synthesis of 


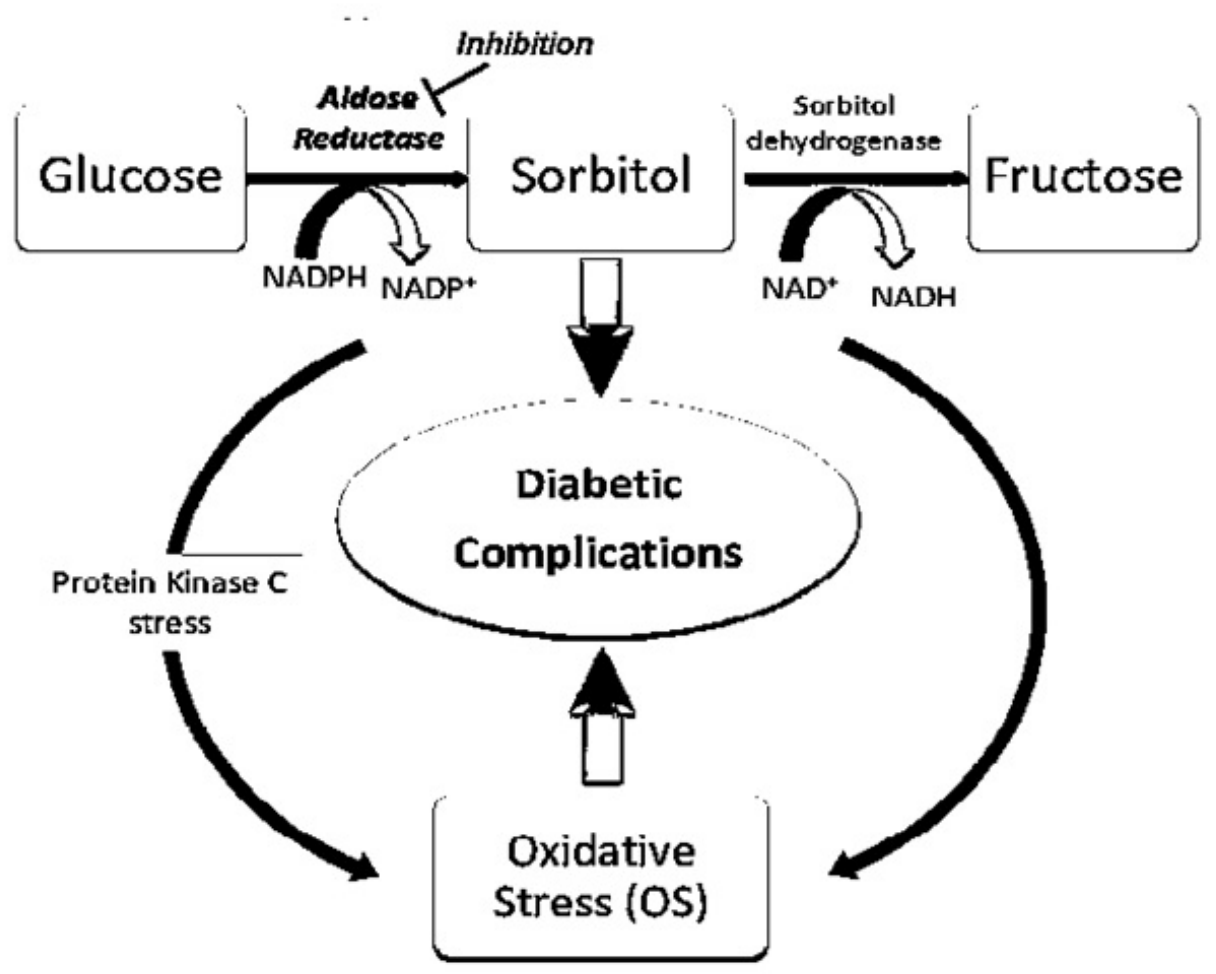

Figure 2: The polyol pathway of glucose metabolism (Modified from: ${ }^{50}$ ).

a Schiff base. The resultant adducts are transiently converted to amadori compounds ${ }^{63}$. The amadori adducts undergo irreversible dehydration and condensation reactions to yield AGEs ${ }^{63,64}$. AGEs are also synthesized from dicarbonyl compounds such as methylglyoxal, 3-deoxyglucosone, and glyoxal, which are outcomes of glucose autoxidation and degradation (Figure 5). Indeed, $\alpha$-hydroxy aldehydes (including glycolaldehyde and glyceraldehyde) are also precursors for AGE synthesis ${ }^{65,66}$. It has been shown that there is increased synthesis and accumulation of AGEs under chronic hyperglycemic conditions, leading to diabetic vascular complications ${ }^{63}$.

The presence of AGEs induces the expression of AGE receptors. The interaction between AGEs and their receptors elevates cellular generation of oxidative stress, enhances the release of cytokines and growth factors via nuclear factor $\kappa \mathrm{B}$ activation, and stimulates adhesion factors, all of which eventually lead to inflammatory response ${ }^{67}$. This interaction between AGEs and their receptor can furthermore escalate arteriosclerosis progression (Figure 4) ${ }^{64,68}$. Aggravations of pathological angiogenesis, reduction in fib- rinolytic activity, unstable angina, and/or acute myocardial infarction are other complications associated with an increase in AGE levels ${ }^{69-71}$.

Drugs such as atorvastatin, pravastatin, telmisartan, ramipril, rosiglitazone, exendin-4 and aminoguanidine have been reported to elicit modulatory effects on the diabetic complications caused by AGEs ${ }^{72-78}$. Atorvastatin, an antioxidant, is known to block the production of $\mathrm{AGEs}^{76}$. Pravastatin is involved in reducing tubular cell destruction in diabetic nephropathy and mitigates cell apoptosis initiated by the $\mathrm{AGEs}^{78}$. The expression of the AGE receptor was blocked by telmisartan in renal mesangial cells, endothelial cells, and liver cells ${ }^{74}$. Telmisartan also ameliorates the production of oxidative stress, inflammation, and arteriosclerosis associated with AGE expression ${ }^{74,77}$. Previously, it has been reported that ramipril elicits similar effects as telmisartan ${ }^{75}$. In addition, rosiglitazone mitigates the expression of AGE receptor, while exendin-4 inhibits the development of diabetic nephropathy by blocking the interaction between AGEs and their receptors in tubular cells. The inhibition of AGE formation by aminoguanidine has also been reported ${ }^{72,73}$. 


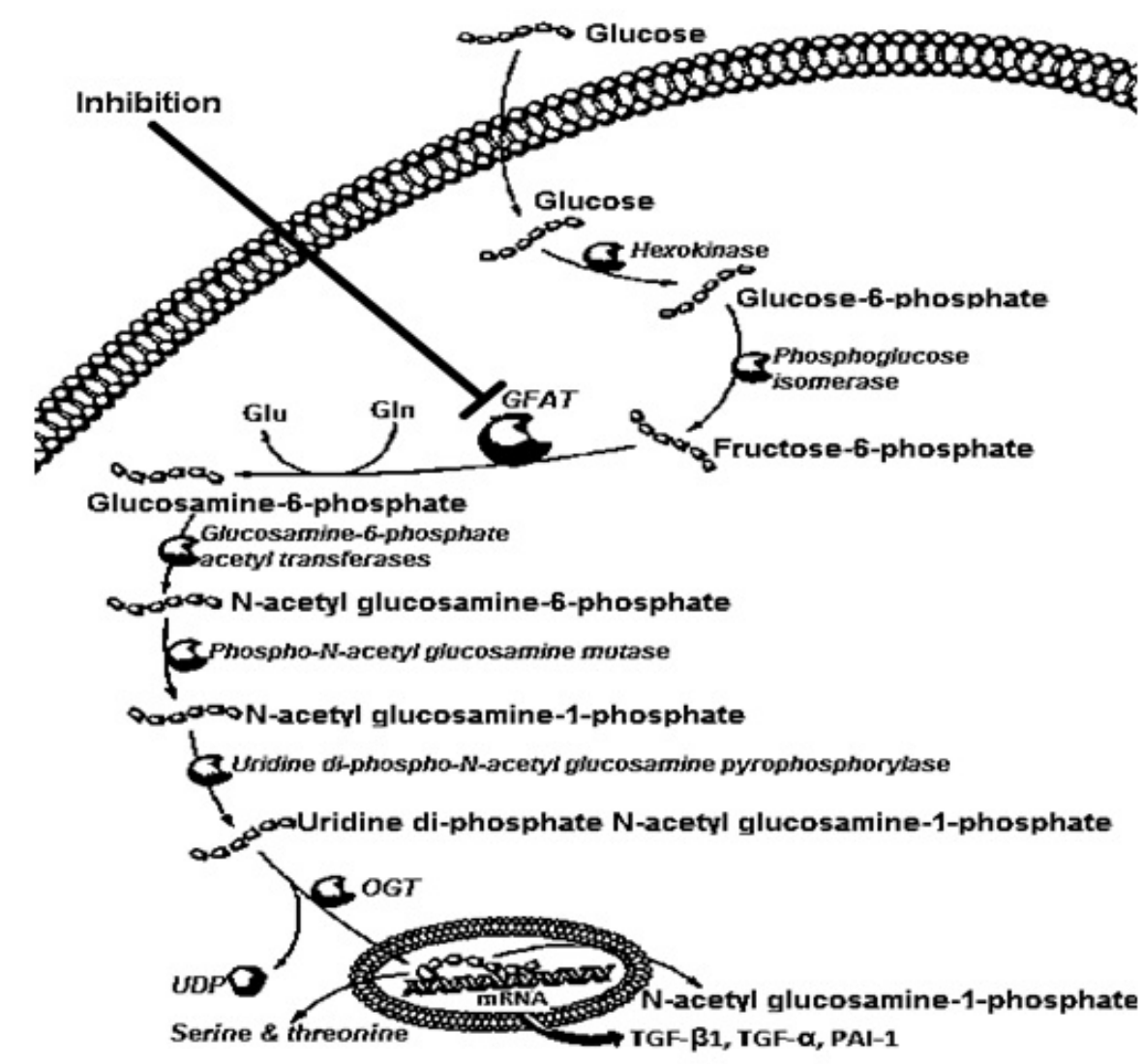

Figure 3: The hexosamine biosynthetic pathway showing the production of the cytokines including TGF$\beta$, ICAM-1, VCAM-1, TNF- $\alpha$, CTGF, PAI-1, involved in various diabetic complications (Modified from: ${ }^{62}$ ). GFAT: glutamine: fructose-6-phosphate-amidotransferase; Glu: glutamate; Gln, glutamine; OGT: O-linked Nacetylglucosamine (O-GIcNAc) transferase; UDP: uridine diphosphate.

\section{Glucose autoxidation}

Hyperglycemia exacerbates the glucose autoxidation process, which leads to the production of harmful reactive species and ketoaldehyde compounds. Specifically, peroxide $\left(\mathrm{H}_{2} \mathrm{O}_{2}\right)$ and malondialdehyde are generated through this mechanism ${ }^{79}$.

Hyperglycemia increases the levels of reactive carbonyl species, such as methylglyoxal and glyoxal, as a result of glucose autoxidation ${ }^{54,80}$. These reactive carbonyl species can preferentially undergo reactivity with arginine and lysine at relatively high rates (Figure 5), thereby provoking DM pathogenesis. Most of the protein binding sites consist of a large number of arginine residues ${ }^{81,82}$. Furthermore, this metabolic process is also linked with the release of AGEs ${ }^{82}$

Generally, the aldehyde group of glucose undergoes reactivity with the $\varepsilon$-amino groups of lysine residues and the $\mathrm{N}$-terminal $\alpha$-amino groups of pro- teins to produce a Schiff base. Subsequently, it undergoes rearrangement to yield an amadori intermediate. The amadori intermediate is further rearranged for the synthesis of heterogeneous AGEs. The arginine residues of proteins are structurally altered by reactive carbonyl species (Figure 5) ${ }^{82}$.

\section{Increased expression of cyclooxygenase (COX)}

Over the years, COX has been known to exist in the cells of mammals in only two isoforms, namely COX1 and $-2^{83}$. However, a third isoform known as COX3 was recently established, although its clinical significance has not been fully confirmed ${ }^{84}$. COX-1 is the most abundant isoform and occurs in almost all tissues $^{83}$. COX-2 is released in trace amounts and is induced by growth factors, PKC activation, inflammatory cytokines, oxidative stress, and tumor promoters $^{85-87}$. 


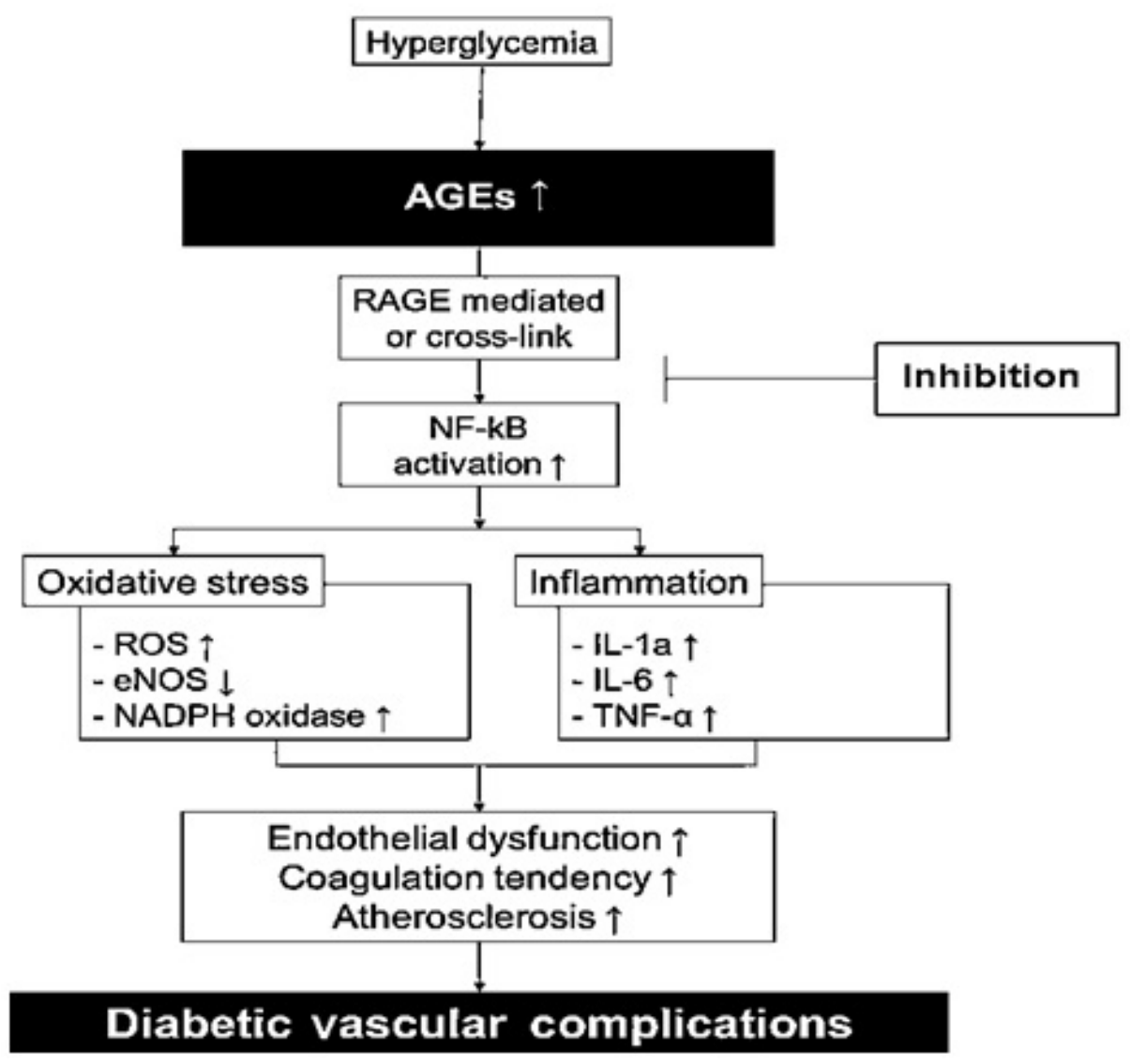

Figure 4: Advanced glycation end-products (AGEs) mechanism in diabetic vascular complications (Modified from: ${ }^{64}$ ). RAGE: advanced glycation end-product receptor; NF- $\kappa$ B: nuclear factor $\kappa B$; IL: interleukin; TNF- $\alpha$ : tumor necrosis factor $\alpha$; ROS: reactive oxygen species; eNOS: endothelial nitric oxide synthase; NADPH: nicotinamide adenine dinucleotide phosphate.

An increase in COX-1 levels has been linked with DM onset, resulting in heart-related disorders with high mortality rates ${ }^{88}$. Furthermore, increased expression and activation of COX-2 have been linked with hyperglycemia through glucose autoxidation and AR pathway activation. This pathway is accompanied by secondary NADPH and $\mathrm{NAD}^{+}$reduction, activation of PKC, stimulation of advanced glycated end-products receptor (RAGE), as well as elevation in reactive oxygen species generation (ROS) (Figure 6) ${ }^{83}$. According to a study carried out by Guo et al., ${ }^{89}$ using type 2 diabetic mice, high COX-2 level was observed in the vascular smooth muscle cells of the mice. An elevation in the abundance of COX- 2 in coronary arterioles was also observed and confirmed in diabetic human subjects $^{90,91}$. High COX-2 level in the podocytes was also observed and subjected the kidneys to diabetic glomerular injury through a (pro) renin-associated mechanism $^{92}$.

Inhibition of COX-2 expression was reported to arrest nephropathy in diabetic subjects ${ }^{93-95}$. In a related study, the inhibitory action of nimesulide against COX-2 improved endothelial dysfunction in the hind limb vasculature of streptozotocin-induced diabetic rats ${ }^{96}$. The inhibitory effect of nonsteroidal antiinflammatory drugs on COX activity has also been extensively reported ${ }^{97,98}$.

\section{Activation of lipoxygenase (LOX)}

Lipoxygenases (LOX) is a family of enzymes typically characterized by non-heme iron-containing structures and is involved in the catalysis of polyunsaturated fatty acid deoxygenation arachidonic acid to generate hydroperoxyl derivatives, such as 


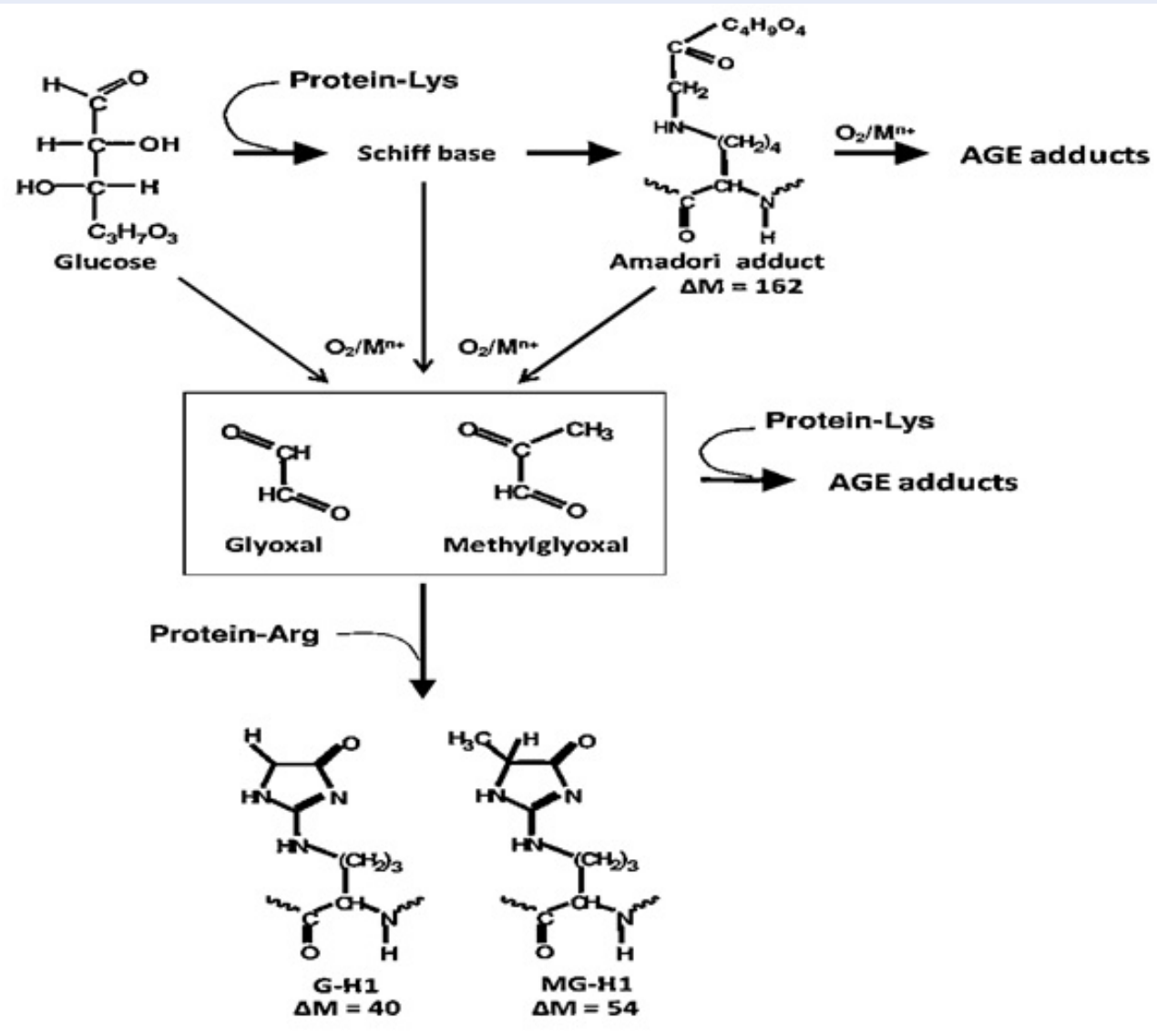

Figure 5: Synthesis of reactive carbonyl species that modify proteins and advanced glycation end products by glucose autoxidation ${ }^{82}$.

hydroperoxy-eicosatetraenoic acids (HPETEs) ${ }^{99}$. The 12-LOX (an isoform of lipoxygenase) is activated by hyperglycemia and free fatty acids or pro-inflammatory cytokines. Furthermore, 12-LOX stimulation promotes the release of the pro-inflammatory lipid intermediates, 12 (S)hydroperoxyeicosatetraenoic acid $\{12(\mathrm{~S})$-HPETE $\}$ and 12 (S)-Hydroxyeicosatetraenoic acid \{12(S)HETE $\}$. These pro-inflammatory lipid intermediatesin concert with NADPH oxidase (NOX), p38 mitogen-activated protein kinases (p38-MAPK), and c-Jun N-terminal kinase (JNK)- can initiate the activation of inflammatory pathways. Eventually, these signaling pathways cause an elevation in ROS, oxidative stress, and endoplasmic reticulum (ER) stress, which can finally lead to impairment and death of $\beta$-cells ${ }^{100}$. The inhibition of the nuclear factor erythroid 2-related factor 2 (Nrf2) translocation by 12 (S)-HETE, which controls the expression of antioxidants, is illustrated in Figure $7^{100,101}$.
ML355 has been reported to be a potent inhibitor of human 12-LOX with an $\mathrm{IC}_{50}$ of $290 \mathrm{~nm}^{102}$. According to Adili et al., ${ }^{103}$ ML355 inhibited 12-LOX oxylipin production in vivo in a dose-dependent manner.

\section{Hexokinase-2 driven glycolytic overload}

Hexokinase-2 is the rate-limiting enzyme that catalyzes the first step of glycolysis, involving the phosphorylation of glucose to glucose-6-phosphate (G6P) ${ }^{105}$. Under hyperglycemic conditions, hexokinase- 2 initiates an abnormal rise in glycolytic metabolic flux without concurrent transcriptional or other functional regulation. The metabolic flux leads to an unusual increase in the level of glycolytic intermediates. This process is known as a glycolytic overload and is accompanied by several diabetic complications ${ }^{104}$. The diabetic pathogenic mechanisms associated with this glycolic overload are as follows: G-6-P induces mitochondrial dysfunction, fruc-6-P 


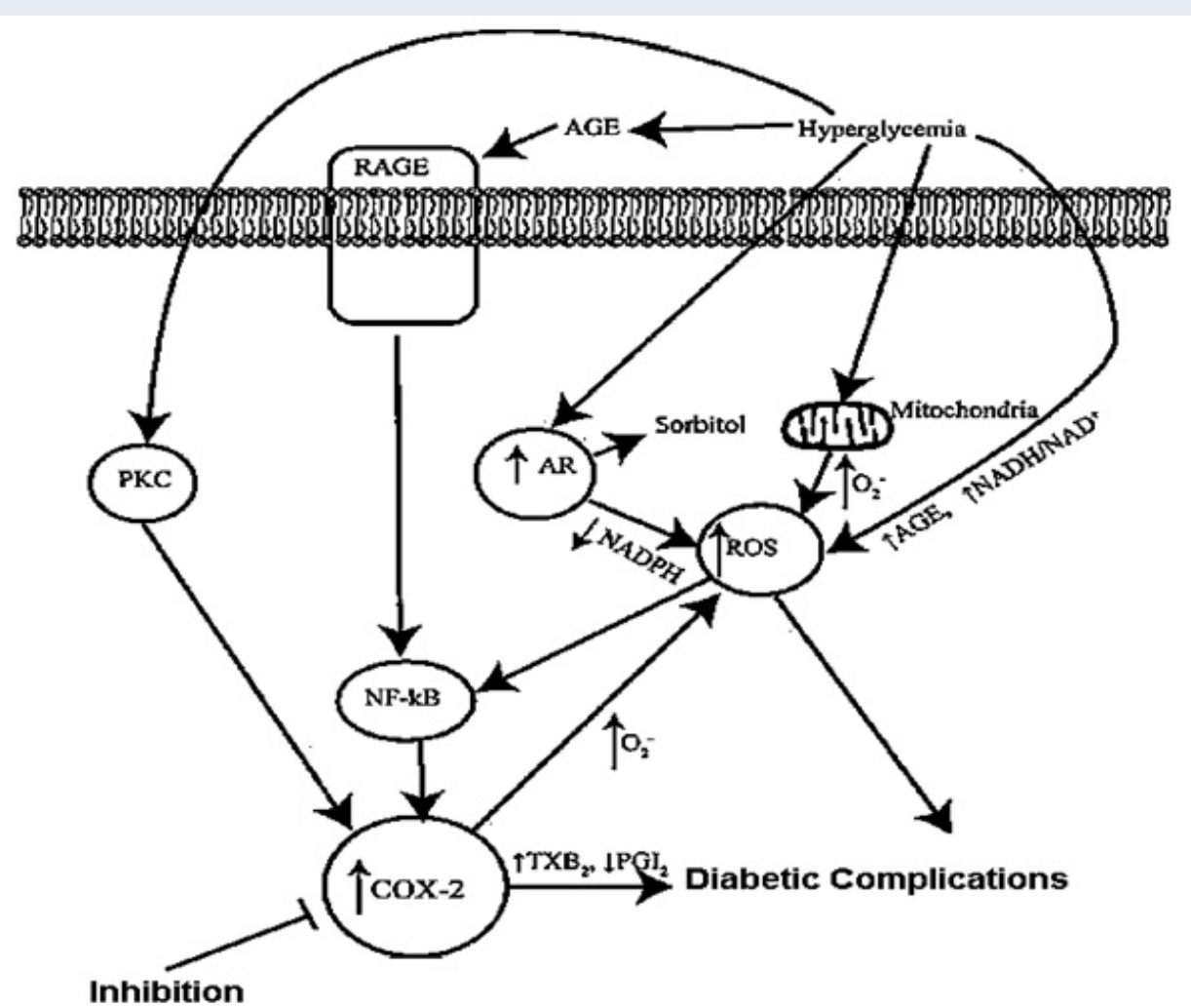

Figure 6: COX-2 activation by hyperglycemia (Modified from: ${ }^{83}$ ). AGE: Advanced glycated end-products; RAGE: Receptor for advanced glycated end-products; PKC: Protein kinase C; AR: Aldose reductase; ROS: Reactive oxygen species; NF-kB: Nuclear factor-kappa B.

is channeled to the hexosamine pathway, and dihydroxyacetone phosphate (DHAP) activates PKC. At the same time, AGEs are formed from methylglyoxal (MG) through glyceraldehyde-3-phosphate and DHAP intermediates (Figure 8) ${ }^{104,106-108}$.

However, a possible therapeutic approach towards the prevention of the complications that may arise from glycolytic overload is through the inhibition of G6P buildup and hexokinase- 2 displacement from the mitochondria. This can be made possible by channeling G6P towards the pentose phosphate pathway through the stimulation of glucose-6-phosphate dehydrogenase. This process also helps in mitigating carbohydrate response element (ChoRE)-linked expression of hexokinase- $2^{109}$.

\section{CONCLUSION}

The disorders associated with DM are linked to various metabolic pathways, facilitated by enzyme activities of the polyol pathway, hexosamine biosynthetic pathway and glucose autoxidation, as well as being associated with increased synthesis of AGE hexokinase-
2 driven glycolytic overload and increased activities of COX, LOX and PKC enzymes. The inhibition of the enzymes involved in these pathways could serve to mitigate and arrest diabetic complications. Thus, suitable inhibitors for enzymes involved in DM metabolic events could serve as panaceas against diabetic complications, and would add to the growing list of new and potentially more effective antidiabetic drugs.

\section{ABBREVIATIONS}

12-HETE: 12(S)-Hydroxyeicosatetraenoic acid

12-HPETE: 12(S)-hydroperoxyeicosatetraenoic acid AGEs: Advanced glycation end-products

AR: Aldose reductase

Arg: Arginine

ChoRE: Carbohydrate response element

COX: Cyclooxygenase

DHAP: Dihydroxyacetone phosphate

DM: Diabetes mellitus

eNOS: Endothelial nitric oxide synthase

ER: Endoplasmic reticulum

F-1, 6-bis-P: Fructose-1, 6-bisphosphate 


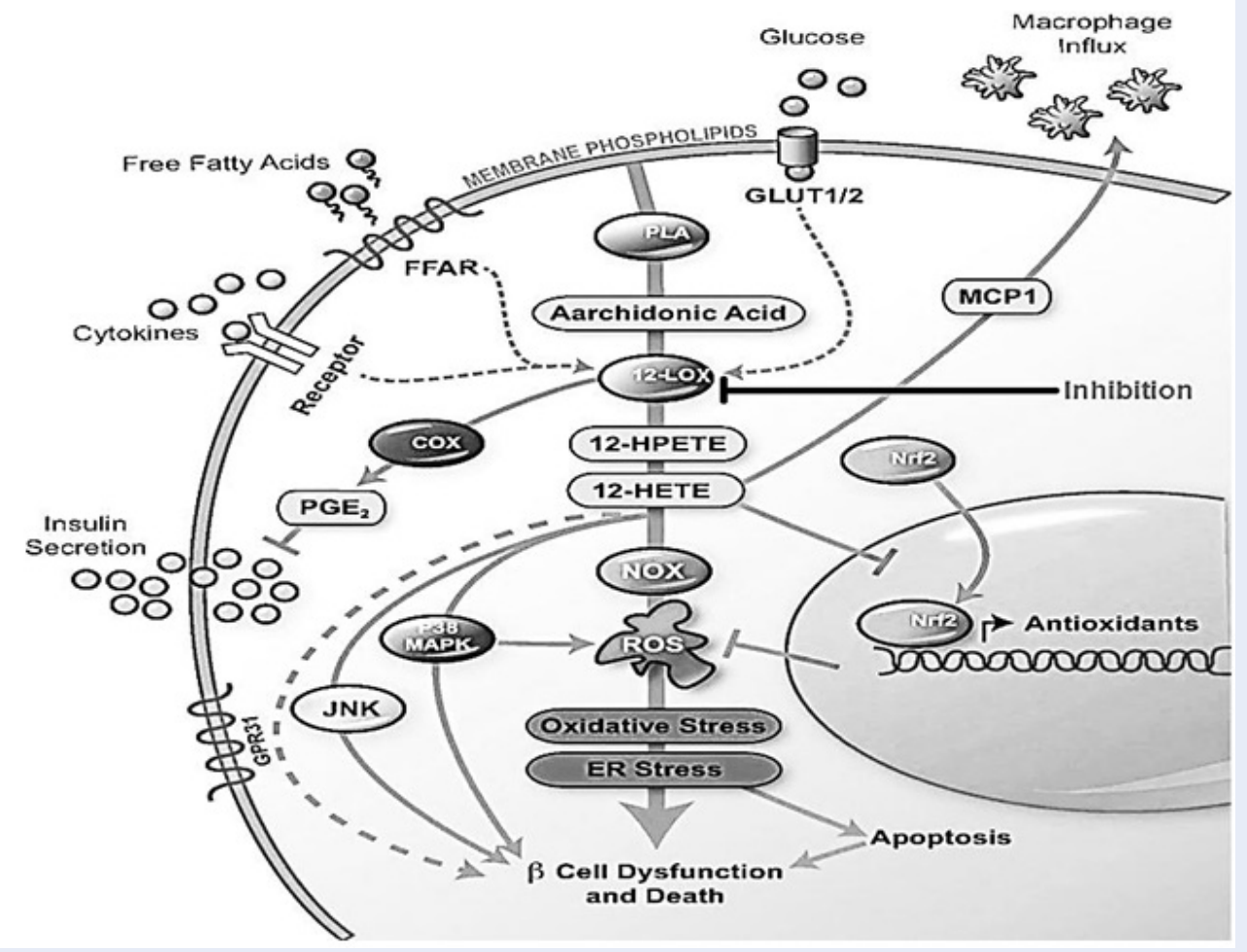

Figure 7: Role of 12-LOX in diabetic complications ${ }^{100,101}$. JNK: c-Jun N-terminal kinase; p38-MAPK: p38 mitogen-activated protein kinases; ROS: Reactive oxygen species; NOX: NADPH Oxidase; 12-HETE: 12(S)Hydroxyeicosatetraenoic acid; 12-HPETE: 12(S)-hydroperoxyeicosatetraenoic acid; 12-LOX: 12-Lipoxygenase; Nrf2: Nuclear factor erythroid 2-related factor 2; ER: Endoplasmic reticulum; FFAR: Free fatty acid receptor; PLA:

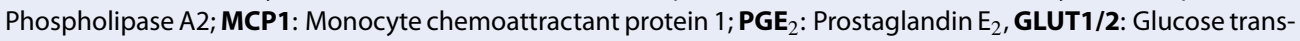
porter 1 or 2.

FFAR: Free fatty acid receptor

Fruc-6-P: Fructose-6-phosphate

G6P: Glucose-6-phosphate

GA3P: Glyceraldehyde-3-phosphate

GFAT: Glutamine: fructose-6-phosphateamidotransferase

Gln: Glutamine

Glu: Glutamate

GLUT1/2: Glucose transporter 1 or 2

IL: Interleukin

JNK: c-Jun N-terminal kinase

LOX: Lipoxygenase

Lys: Lysine

MCP1: Monocyte chemoattractant protein 1

MG: Methylglyoxal

NADPH: Nicotinamide adenine dinucleotide phosphate

NF-kB: Nuclear factor-kappa B

NF- $\kappa$ B: Nuclear factor $\kappa$ B

NOX: Nicotinamide adenine dinucleotide phosphate oxidase
Nrf2: Nuclear factor erythroid 2-related factor 2

OGT: O-linked $\mathrm{N}$-acetylglucosamine (O-GlcNAc) transferase

p38-MAPK: p38 mitogen-activated protein kinases

PGE2: Prostaglandin E2

PKC: Protein kinase C

PLA: Phospholipase A2

RAGE: Advanced glycation end-product receptor ROS: Reactive oxygen species

SD: sorbitol dehydrogenase

TNF- $\alpha$ : Tumor necrosis factor $\alpha$

TPI: Triosephosphate isomerase

UDP: Uridine diphosphate

UDP- $N$-acetylglucosamine: uridine-5-diphosphate$\mathrm{N}$-acetylglucosamine

\section{ACKNOWLEDGMENTS}

None. 


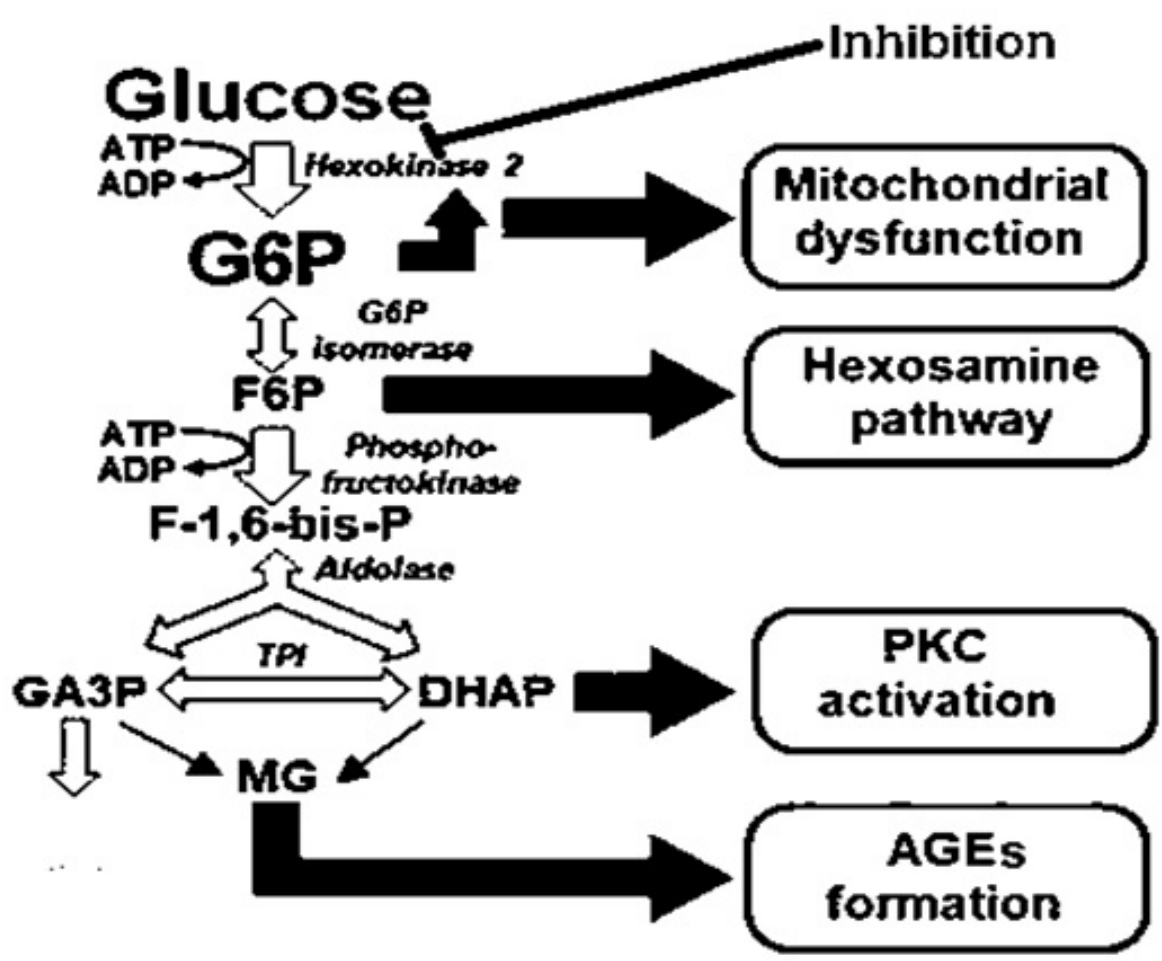

Figure 8: Downstream diabetic consequences of hexokinase-2 driven glycolytic overload. (Modified from: ${ }^{104}$ ). G6P: Glucose-6-phosphate; Fruc-6-P: fructose-6-phosphate; F-1, 6-bis-P: fructose-1, 6-bisphosphate; TPI: Triose phosphate isomerase; DHAP: Dihydroxyacetone phosphate; GA3P: Glyceraldehyde-3-phosphate; MG: methylglyoxal; PKC: Protein kinase C; AGE: Advanced glycation end-products.

\section{AUTHORS' CONTRIBUTIONS}

FOO/PCC conceived and designed the scope of the report. FOO/PCC/CMC contributed in writing the paper. FOO/PCC revised and edited the manuscript draft. FOO/PCC/CMC authors were the resource persons who provided all the necessary materials for writing the manuscript. FOO/PCC/CMC approved the manuscript in the present form and gave permission to submit the manuscript for publication.

\section{FUNDING}

None.

\section{AVAILABILITY OF DATA AND MATERIALS}

Not applicable.

\section{ETHICS APPROVAL AND CONSENT TO PARTICIPATE}

Not applicable.

\section{CONSENT FOR PUBLICATION}

Not applicable.

\section{COMPETING INTERESTS}

The authors declare that they have no competing interests.

\section{REFERENCES}

1. Unuofin JO, Lebelo SL. Antioxidant Effects and mechanisms of medicinal plants and their bioactive compounds for the prevention and treatment of type 2 diabetes: An updated review. Oxidative Medicine and Cellular Longevity. 2020; 2020, Article ID 1356893, 36 ;PMID: 32148647 . Available from: https://doi.org/10.1155/2020/1356893.

2. Forbes JM, Cooper ME. Mechanisms of diabetic complications. Physiological Review. 2013;93:137-88;PMID: 23303908. Available from: https://doi.org/10.1152/physrev. 00045.2011.

3. International Diabetes Federation (IDF). Diabetes Atlas 2017 , 8th edition. 2017;. 
4. Danaei G, Finucane MM, Lu Y, Singh GM, Cowan MJ, Paciorek CJ, Lin JK, Farzadfar F, Khang YH, Stevens GA, Rao M, Ali MK, Riley LM, Robinson CA, Ezzati M. National, regional, and global trends in fasting plasma glucose and diabetes prevalence since 1980: Systematic analysis of health examination surveys and epidemiological studies with 370 countryyears and 2.7 million participants. Lancet. 2011;378:3140;Available from: https://doi.org/10.1016/S0140-6736(11) 60679-X.

5. Mathis $D$, Vence $L$, Benoist $C$. Beta-cell death during progression to diabetes. Nature. 2001;414:792-8;PMID: 11742411. Available from: https://doi.org/10.1038/414792a.

6. Keenan HA, Sun JK, Levine J, Doria A, Aiello LP, Eisenbarth $G$, Bonner-Weir S, King GL. Residual insulin production and pancreatic $\beta$-cell turnover after 50 years of diabetes: Joslin Medalist Study. Diabetes. 2010;59:2846-53;PMID: 20699420. Available from: https://doi.org/10.2337/db10-0676.

7. Cerf ME. Beta-cell dysfunction and insulin resistance. Frontiers in Endocrinology. 2013;4:37;PMID: 23542897. Available from: https://doi.org/10.3389/fendo.2013.00037.

8. Kitada M, Zhang Z, Mima A, King GL. Molecular mechanisms of diabetic vascular complications. Journal of Diabetes Investigation. 2010;1(3):77-89;Available from: https://doi.org/ 10.1111/j.2040-1124.2010.00018.x.

9. Alam F, Shafique Z, Amjad ST, BinAsad MHH. Enzymes inhibitors from natural sources with antidiabetic activity: A review. Phytotherapy Research. 2019;33:41-54;PMID: 30417583. Available from: https://doi.org/10.1002/ptr.6211.

10. Gilbertson DT, Liu J, Xue JL, Louis TA, Solid CA, Ebben JP, Collins AJ. Projecting the number of patients with endstage renal disease in the United States to the year 2015. Journal of America Society of Nephrology. 2005;16:373641;PMID: 16267160. Available from: https://doi.org/10.1681/ ASN.2005010112.

11. UK Prospective Diabetes Study Group (UKPDS). Intensive blood-glucose control with sulphonylureas or insulin compared with conventional treatment and risk of complications in patients with type 2 diabetes (UKPDS 33). Lancet. 1998;352:837-53;PMID: 9742976. Available from: https://doi. org/10.1016/S0140-6736(98)07019-6.

12. Amico JA, Klein I. Diabetic management in patients with renal failure. Diabetes Care. 1981;4:430-4;PMID: 7047117. Available from: https://doi.org/10.2337/diacare.4.3.430.

13. Frank RN. Diabetic retinopathy. New England Journal of Medicine. 2004;350:48-58;PMID: 14702427. Available from: https://doi.org/10.1056/NEJMra021678.

14. Hirai FE, Tielsch JM, Klein BE, Klein R. Ten-year change in vision-related quality of life in type 1 diabetes: Wisconsin epidemiologic study of diabetic retinopathy. Ophthalmology. 2011;118:353-8;Available from: https://doi.org/10.1016/ j.ophtha.2010.06.022.

15. Abbott CA, Malik RA, van Ross ER, Kulkarni J, Boulton AJ. Prevalence and characteristics of painful diabetic neuropathy in a large community-based diabetic population in the UK. Diabetes Care. 2011;34:2220-4;PMID: 21852677. Available from: https://doi.org/10.2337/dc11-1108.

16. Colloca $L$, Ludman $T$, Bouhassira $D$, Baron $R$, Dickenson AH, Yarnitsky D, Freeman R, Truini A, Attal N, Finnerup NB, Eccleston C, Kalso E, Bennett DL, Dworkin RH, Raja SN. Neuropathic pain. Nature Reviews Disease Primers. 2017;3:17002;PMID: 28205574. Available from: https://doi. org/10.1038/nrdp.2017.2.

17. Obrosova IG. Diabetic painful and insensate neuropathy: pathogenesis and potential treatments. Neurotherapy. 2009;6:638-47;Available from: https://doi.org/10.1016/j.nurt. 2009.07.004.

18. Laing SP, Swerdlow AJ, Slater SD, Burden AC, Morris A, Waugh NR, Gatling W, Bingley PJ, Patterson CC. Mortality from heart disease in a cohort of 23, 000 patients with insulin-treated diabetes. Diabetology. 2003;46:760-5;PMID: 12774166. Available from: https://doi.org/10.1007/s00125003-1116-6.
19. Haffner SM, Lehto S, Ronnemaa T, Pyorala K, Laakso M. Mortality from coronary heart disease in subjects with type $2 \mathrm{di}$ abetes and in nondiabetic subjects with and without prior myocardial infarction. New England Journal of Medicine. 1998;339:229-34;PMID: 9673301. Available from: https://doi. org/10.1056/NEJM199807233390404.

20. Prince $C T$, Becker DJ, Costacou T, Miller RG, Orchard TJ. Changes in glycemic control and risk of coronary artery disease in type 1 diabetes mellitus: Findings from the Pittsburgh Epidemiology of Diabetes Complications Study (EDC). Diabetologia. 2007;50:2280-8;PMID: 17768606. Available from: https://doi.org/10.1007/s00125-007-0797-7.

21. Groop PH, Thomas MC, Moran JL, Waden J, Thorn LM, Makinen VP, Rosengard-Barlund M, Saraheimo M, Hietala K, Heikkila O, Forsblom C. The presence and severity of chronic kidney disease predicts all-cause mortality in type 1 diabetes. Diabetes. 2009;58:1651-8;PMID: 19401416. Available from: https://doi.org/10.2337/db08-1543.

22. Drury PL, Ting R, Zannino D, Ehnholm C, Flack J, Whiting M, Fassett R, Ansquer JC,Dixon P, Davis TM, Pardy C, Colman $P$, Keech A. Estimated glomerular filtration rate and albuminuria are independent predictors of cardiovascular events and death in type 2 diabetes mellitus: The Fenofibrate $\mathrm{In}$ tervention and Event Lowering in Diabetes (FIELD) study. Diabetologia. 2011;54:32-43;PMID: 20668832. Available from: https://doi.org/10.1007/s00125-010-1854-1.

23. Brownlee M. Biochemistry and molecular cell biology of diabetic complications. Nature. 2001;414:813-20;PMID: 11742414. Available from: https://doi.org/10.1038/ 414813ahttps://doi.org/10.1038/414813a.

24. Aiello LP, Cahill MT, Cavallerano JD. Growth factors and protein kinase $C$ inhibitors as novel therapies for the medical management diabetic retinopathy. Eye. 2004;18:11725;PMID: 14762400. Available from: https://doi.org/10.1038/ sj.eye.6700585.

25. Geraldes $\mathrm{P}$, King GL. Activation of protein kinase $\mathrm{C}$ isoforms and its impact on diabetic complications. Circulation Research. 2010;106:1319-31;Available from: https://doi.org/10. 1161/CIRCRESAHA.110.217117.

26. Bennett SP, Griffiths GD, Schor AM, Leese GP, Schor SL. Growth factors in the treatment of diabetic foot ulcers. British Journal of Surgery. 2003;90:133-46;PMID: 12555288. Available from: https://doi.org/10.1002/bjs.4019.

27. Pathak D, Gupta A, Kamble B, Kuppusamy G, Suresh B. Oral targeting of protein kinase $C$ receptor: promising route for diabetic retinopathy? Current Drug Delivery. 2012;9:40513;PMID: 22520069. Available from: https://doi.org/10.2174/ 156720112801323080.

28. Shi GJ, Shi GR, Zhou J, Zhang W, Gao C, Jiang Y, Zi Z, Zhao H, Yang $Y, Y$ J J (2018) Involvement of growth factors in diabetes mellitus and its complications: A general review. Biomedicine and Pharmacotherapy. 101:510-27;PMID: 29505922. Available from: https://doi.org/10.1016/j.biopha. 2018.02.105.

29. Mathebula SD. Polyol pathway: A possible mechanism of diabetes complications in the eye. African Vision and Eye Health. 74:13. 2015;Available from: https://doi.org/10.4102/ aveh.v74i1.13.

30. Naidu PB, Uddandrao VVS, Naik RR, Pothani S, Munipally PK , Meriga B, Begum MS, Varatharaju C, Pandiyan R, Saravanan G. Effects of S-allylcysteine on biomarkers of the polyol pathway in rats with type 2 diabetes. Canadian Journal of Diabetes. 2016;40:442-8;PMID: 27373435. Available from: https: //doi.org/10.1016/j.jcjd.2016.03.006.

31. Sharavana G, Joseph GS, Baskaran V. Lutein attenuates oxidative stress markers and ameliorates glucose homeostasis through polyol pathway in heart and kidney of STZinduced hyperglycemic rat model. European Journal of Nutrition. 2017;56:2475-85;PMID: 27488609. Available from: https://doi.org/10.1007/s00394-016-1283-0.

32. Koya $D$, Jirousek MR, Lin YW, Ishii $H$, Kuboki K, King GL. 
Characterization of protein kinase $C \beta$-isoform activation on the gene expression of transforming growth factor-beta, extracellular matrix components, and prostanoids in the glomeruli of diabetic rats. Journal of Clinical Investigations. 1997;100:115-26;PMID: 9202063. Available from: https://doi. org/10.1172/JCI119503.

33. Huang $P$, Zhang YJ, Huang Y, Zhao JJ, Jiang T, Zhang N. Effect of PKC signaling pathway and aldose reductase on expression of fibronectin induced by transforming growth factor$\beta 1$ in human mesangial cells. Chinese Journal of Pathology. 2010;39:405-9;PMID: 21055159.

34. Thomas K, Zhang M, Reinicke J, Parker J, Ohora D, Wall MM, Songsak T, Wongwiwatthananukit S, Chang LC. Protein kinase inhibitory properties of extracts derived from Bocconia frutescens and Gomphocarpus physocarpus. Bulletin of Health Science and Technology. 2017;15:47-58;Available from: https://www.ars.usda.gov/research/publications/ publication/?seqNo115=341115.

35. Soriano FG, Virág L, Jagtap P, Szabó É, Mabley JG, Liaudet L, Marton A, Hoyt DG, Murthy KGK, Salzman AL, Southan GJ, Szabó C. Diabetic endothelial dysfunction: the role of poly (ADP-ribose) polymerase activation. Nature Medicine. 2001;7:108-13;PMID: 11135624. Available from: https://doi. org/10.1038/83241.

36. Prnova MS, Ballekova J, Gajdosikova A, Gajdosik A, Stefek M. A novel carboxymethylated mercaptotriazinoindole inhibitor of aldose reductase interferes with the polyol pathway in streptozotocin-induced diabetic rats. Physiology Research. 2015;64:587-91;PMID: 26291727. Available from: https://doi.org/10.33549/physiolres.933034.

37. Boesten DMPHJ, Ungern-Sternberg SNIV, Hartog GJMD, Bast A. Protective pleiotropic effect of flavonoids on NAD+ levels in endothelial cells exposed to high glucose. Oxidative Medicine and Cellular Longevity. 2015;2015, Article ID 894597, 7 pages;PMID: 26180598. Available from: https: //doi.org/10.1155/2015/894597.

38. Shakeel M. Recent advances in understanding the role of oxidative stress in diabetic neuropathy. Diabetes and Metabolic Syndrome: Clinical Research and Review. 2015;9:373-8;PMID: 25470637. Available from: https://doi.org/10.1016/j.dsx.2014.04.029.

39. Li F, Zhao YB, Wang DK, Zou X, Fang K, Wang KF. Berberine relieves insulin resistance via the cholinergic antiinflammatory pathway in HepG2 cells. Jouranl of Huazhong University of Science and Technology-Medical Science. 2016;36:64-69;PMID: 26838742. Available from: https://doi. org/10.1007/s11596-016-1543-5.

40. Jang DS, Yoo NH, Kim JM, Lee YM, Yoo JL, Kim YS, Kim JS. An ellagic acid rhamnoside from the roots of Potentilla discolor with protein glycation and rat lens aldose reductase inhibitory activity. Natural Product Science. 2007;13:160-3;

41. Aida K, Tawata M, Shindo H, Onaya T, Sasaki H, Yamaguchi $\mathrm{T}$, Chin M, Mitsuhashi H. Isoliquiritigenin: A new aldose reductase inhibitor from Glycyrrhizae radix. Planta Medicine. 1990;56:254-8;PMID: 2118267. Available from: https://doi. org/10.1055/s-2006-960950.

42. Jung SH, Lee YS, Lee S, Lim SS, Kim YS, Shin KH. Isoflavonoids from the rhizomes of Belamcanda chinensis and their effects on aldose reductase and sorbitol accumulation in streptozotocin induced diabetic rat tissues. Archives of Pharmacal Research. 2002;25:306-12;PMID: 12135102. Available from: https://doi.org/10.1007/BF02976631.

43. Shin KH, Kang SS, Seo EA, Shin SW. Isolation of aldose reductase inhibitors from the flowers of Chrysanthemum boreale. Archives of Pharmacal Research. 1995;18:65;Available from: https://doi.org/10.1007/BF02979135.

44. Fuente JA, Manzanaro S. Aldose reductase inhibitors from natural sources. Natural Product Reports. 2003;20:24351;PMID: 12735699. Available from: https://doi.org/10.1039/ b204709h.

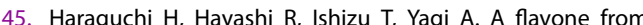
Manilkara indica as a specific inhibitor against aldose reductase in vitro. Planta Medicine. 2003;69:853-5;PMID: 14598214. Available from: https://doi.org/10.1055/s-200343218.

46. Kato A, Yasuko H, Goto H, Hollinshead J, Nash RJ, Adachi I. Inhibitory effect of rhetsinine isolated from Evodia rutaecarpa on aldose reductase activity. Phytomedicine. 2009;16:25861;PMID: 17498942. Available from: https://doi.org/10.1016/ j.phymed.2007.04.008.

47. Kadota $S$, Basnet $P$, Hase $K$, Namba T. Matteuorienate A and $B$, two new and potent aldose reductase inhibitors from Matteuccia orientalis. Chemical and Pharmaceutical Bulletin. 1994;42:1712-4;PMID: 7954926. Available from: https://doi. org/10.1248/cpb.42.1712.

48. Kim NH, Kim YS, Lee YM, Jang DS, Kim JS. Inhibition of aldose reductase and xylose-induced lens opacity by puerariafuran from the roots of Pueraria lobata. Biological and Pharmaceutical Bulletin. 2010;33:1605-9;PMID: 20823582. Available from: https://doi.org/10.1248/bpb.33.1605.

49. Guvenc A, Okada Y, Akkol EK, Duman H, Okuyama T, Calis I. Investigations of anti-inflammatory, anti-nociceptive, antioxidant and aldose reductase inhibitory activities of phenolic compounds from Sideritis brevibracteata. Food Chemistry. 2010;118:686-92;Available from: https://doi.org/ 10.1016/j.foodchem.2009.05.034.

50. Digiacomo M, Sartini S, Nesi G, Sestito S, Coviello V, LaMotta C, Rapposelli S. Synthesis and functional evaluation of novel aldose reductase inhibitors bearing a spirobenzopyran scaffold. Open Journal of Medical Chemistry. 2017;11:923;PMID: 28567125. Available from: https://doi.org/10.2174/ 1874104501711010009 .

51. Schleicher ED, Weigert C. Role of the hexosamine biosynthetic pathway in diabetic nephropathy. Kidney International. 2000;58:S13-8;Available from: https://doi.org/10.1046/ j.1523-1755.2000.07703.x.

52. Marshall S, Bacote V, Traxinger RR. Discovery of a metabolic pathway mediating glucose-induced desensitization of the glucose transport system: Role of hexosamine biosynthesis in the induction of insulin resistance. Journal of Biological Chemistry. 1991;266:4706-12;PMID: 2002019. Available from: https://www.jbc.org/article/S0021-9258(19)677069/pdf.

53. Kolm-Litty V, Sauer U, Nerlich A, Lehmann R, Schleicher ED. High glucose-induced transforming growth factor $\beta-1$ production is mediated by the hexosamine pathway in porcine glomerular mesangial cells. Journal of Clinical Investigation. 1998;101:160-9;PMID: 9421478. Available from: https://doi. org/10.1172/JCI119875.

54. Giacco F, Brownlee M. Oxidative stress and diabetic complications. Circulation Research. 2010;107:1058-70;Available from: https://doi.org/10.1161/CIRCRESAHA.110.223545.

55. Beriault D, Shi $Y$, Werstuck $G$. Investigating the role of the hexosamine biosynthesis pathway in diabetic atherosclerosis. Canadian Journal of Cardiology. 2013;29:S254;Available from: https://doi.org/10.1016/j.cjca.2013.07.417.

56. Marsh SA, Dellltalia LJ, Chatham JC. Activation of the hexosamine biosynthesis pathway and protein O-GICNAacylation modulate hypertrophic and cell signaling pathways in cardiomyocytes from diabetic mice. Amino Acids. 2011;40:819-28;PMID: 20676904. Available from: https://doi. org/10.1007/s00726-010-0699-8.

57. Taparra K, Tran PT, Zachara NE. Hijacking the hexosamine biosynthetic pathway to promote EMT-mediated neoplastic phenotypes. Frontiers in Oncology. 2016;6;PMID: 27148477. Available from: https://doi.org/10.3389/fonc.2016.00085.

58. Chiaradonna F, Ricciardiello F, Palorini R. The nutrientsensing hexosamine biosynthetic pathway as the hub of cancer metabolic rewiring. Cells. 2018;7:53;PMID: 29865240. Available from: https://doi.org/10.3390/cells7060053.

59. Pang $Y$, Bounelis $P$, Chatham JC, Marchase RB. Hexosamine pathway is responsible for inhibition by diabetes of phenylephrine-induced inotropy. Diabetes. 
2004:53:1074-81;PMID: $15047624 . \quad$ Available from: https://doi.org/10.2337/diabetes.53.4.1074.

60. Shetty AK, Salimath PV. Reno-protective effects of fenugreek (Trigonella foenumgreacum) during experimental diabetes. e-SPEN Journal. 2009;4:e137-42;Available from: https://doi. org/10.1016/j.eclnm.2009.02.002.

61. Nguyen VTH, Tran N, Nguyen D, Le L. An in silico study on antidiabetic activity of bioactive compounds in Euphorbia thymifolia Linn. SpringerPlus. 2016;5:1359;PMID: 27588252. Available from: https://doi.org/10.1186/s40064-016-2631-5.

62. Vyas B, Silakari O, Singh BM, Singh B. Glutamine: fructose6-phosphate amidotransferase (GFAT): Homology modelling and designing of new inhibitors using pharmacophore and docking based hierarchical virtual screening protocol. SAR and QSAR in Environmental Research. 2013;24:73352;Available from: https://doi.org/10.1080/1062936X.2013. 797493.

63. Yamagishi S, Imaizumi T. Diabetic vascular complications: Pathophysiology, biochemical basis and potential therapeutic strategy. Current Pharmaceutical Design. 2005;11:227999;PMID: 16022668. Available from: https://doi.org/10.2174/ 1381612054367300.

64. Rhee SY, Kim YS. The Role of advanced glycation end products in diabetic vascular complications. Diabetes and Metabolism Journal. 2018;42:188-95;PMID: 29885110. Available from: https://doi.org/10.4093/dmj.2017.0105.

65. Lo TW, Westwood ME, McLellan AC, Selwood T, Thornalley PJ. Binding and modification of proteins by methylglyoxal under physiological conditions. A kinetic and mechanistic study with $\mathrm{N}$ alpha-acetylarginine, $\mathrm{N}$ alpha-acetylcysteine, and $\mathrm{N}$ alpha-acetyllysine, and bovine serum albumin. Journal of Biological Chemistry. 1994;269:32299-305;PMID: 7798230. Available from: https://doi.org/10.1016/S00219258(18)31635-1.

66. Ahmed N, Thornalley PJ, Dawczynski J, Franke S, Strobel J, Stein G, Haik GM. Methylglyoxal-derived hydroimidazolone advanced glycation end-products of human lens proteins. Investigative Ophthalmology and Visual Science. 2003;44:5287-92;PMID: 14638728. Available from: https:// doi.org/10.1167/iovs.03-0573.

67. Naka Y, Bucciarelli LG, Wendt T, Lee LK, Rong LL, Ramasamy $R$, Yan SF, Schmidt AM. RAGE axis: Animal models and novel insights into the vascular complications of diabetes. Arteriosclerosis Thrombosis and Vascular Biology. 2004;24:13429;PMID: 15155381. Available from: https://doi.org/10.1161/ 01.ATV.0000133191.71196.90.

68. Xu B, Ji Y, Yao K, Cao YX, Ferro A. Inhibition of human endothelial cell nitric oxide synthesis by advanced glycation end-products but not glucose: relevance to diabetes. Clinical Science (London). 2005;109:439-446;PMID: 16022682. Available from: https://doi.org/10.1042/CS20050183.

69. Yamagishi S, Adachi H, Takeuchi M, Enomoto M, Furuki K, Matsui T, Nakamura K, Imaizumi T. Serum level of advanced glycation end-products (AGEs) is an independent determinant of plasminogen activator inhibitor-1 (PAl-1) in nondiabetic general population. Hormone and Metabolic Research. 2007;39:845-8;PMID: 17992643. Available from: https://doi. org/10.1055/s-2007-991176.

70. Singh VP, Bali A, Singh N, Jaggi AS. Advanced glycation end products and diabetic complications. Korean Journal of Physiology and Pharmacology. 2014;18:1-14;PMID: 24634591. Available from: https://doi.org/10.4196/kjpp.2014. 18.1.1.

71. Yamagishi S. Role of advanced glycation end products (AGEs) and receptor for AGEs (RAGE) in vascular damage in diabetes. Experimental Gerontology. 2011:46:217-24;PMID: 21111800 Available from: https://doi.org/10.1016/j.exger.2010.11.007.

72. Thornalley PJ, Yurek-George A, Argirov OK. Kinetics and mechanism of the reaction of aminoguanidine with the alpha-oxoaldehydes glyoxal, methylglyoxal, and 3-deoxyglucosone under physiological conditions. Biochemical Pharmacology. 2000;60:55-65;Available from:
https://doi.org/10.1016/S0006-2952(00)00287-2.

73. Forbes JM, Yee LT, Thallas V, Lassila M, Candido R, JandeleitDahm KA, Thomas MC, Burns WC, Deemer EK, Thorpe SR, Cooper ME, Allen TJ. Advanced glycation end product interventions reduce diabetes-accelerated atherosclerosis. Diabetes. 2004;53:1813-23;Available from: https://doi.org/10. 2337/diabetes.53.7.1813.

74. Yamagishi S, Nakamura K, Matsui T. Potential utility of telmisartan, an angiotensin II type 1 receptor blocker with peroxisome proliferator-activated receptor-gamma (PPAR-gamma)-modulating activity for the treatment of cardiometabolic disorders. Current Molecular Medicine. 2007a;7:463-69;Available from: https://doi.org/10.2174/156652407781387073.

75. Coughlan MT, Thallas-Bonke V, Pete J, Long DM, Gasser A, Tong DC, Arnstein M, Thorpe SR, Cooper ME, Forbes JM. Combination therapy with the advanced glycation end product cross-links breaker, alagebrium, and angiotensin converting enzyme inhibitors in diabetes: synergy or redundancy? Endocrinology. 2007;148:886-95;Available from: https://doi. org/10.1210/en.2006-1300.

76. Yamagishi S. Possible involvement of advanced glycation end products in carry-over benefits of atorvastatin in ASCOTBPLA. European Heart Journal. 2008;29:1922;Available from: https://doi.org/10.1093/eurheartj/ehn244.

77. Yamagishi S, Nakamura K, Matsui T. Regulation of advanced glycation end product (AGE)-receptor (RAGE) system by PPAR-gamma agonists and its implication in cardiovascular disease. Pharmacology Research. 2009;60:174-8;PMID: 19646657. Available from: https://doi.org/10.1016/j.phrs. 2009.01.006.

78. Ishibashi Y, Yamagishi S, Matsui T, Ohta K, Tanoue R, Takeuchi M, Ueda S, Nakamura K, Okuda S. Pravastatin inhibits advanced glycation end products (AGEs)-induced proximal tubular cell apoptosis and injury by reducing receptor for AGEs (RAGE) level. Metabolism. 2012;61:1067-72;Available from: https://doi.org/10.1016/j.metabol.2012.01.006.

79. Yaribeygi H, Atkin SL, Sahebkar A. A review of the molecular mechanisms of hyperglycemia-induced free radical generation leading to oxidative stress. Journal of Cell Physiology. 2019;234:1300-1312;PMID: 30146696. Available from: https://doi.org/10.1002/jcp.27164.

80. Thornalley PJ, Langborg A, Minhas HS. Formation of glyoxal, methylglyoxal and 3-deoxyglucosone in the glycation of proteins by glucose. Biochemistry Journal. 1999;344:10916;Available from: https://doi.org/10.1042/bj3440109.

81. Rabbani N, Thornalley PJ. Methylglyoxal, glyoxalase 1 and the dicarbonyl proteome. Amino Acids. 2010;42:113342;PMID: 20963454. Available from: https://doi.org/10.1007/ s00726-010-0783-0.

82. Chetyrkin S, Mathis M, Pedchenko V, Sanchez OA, McDonald WH, Hachey DL, Madu H, Stec D, Hudson B, Voziyan P. Glucose autoxidation induces functional damage to proteins via modification of critical arginine residues. Biochemistry. 2011;50:6102-12;PMID: 21661747. Available from: https:// doi.org/10.1021/bi200757d.

83. Kellogg AP, Cheng, HT, Pop-Busui R. Cyclooxygenase2 pathway as a potential therapeutic target in diabetic peripheral neuropathy. Current Drug Targets. 2008;9:6876;PMID: 18220714. Available from: https://doi.org/10.2174/ 138945008783431691

84. Kis B, Snipes JA, Busija DW. Acetaminophen and the cyclooxygenase-3 puzzle: Sorting out facts, fictions, and uncertainties. Journal of Pharmacology and Experimental Therapeutics. 2005;315:1-7;PMID: 15879007. Available from: https://doi.org/10.1124/jpet.105.085431.

85. Cosentino F, Eto M, De Paolis P, van der Loo B, Bachschmid M, Ullrich V, Kouroedov A, Delli Gatti C, Joch H, Volpe M, Luscher TF. High glucose causes upregulation of cyclooxygenase2 and alters prostanoid profile in human endothelial cells: Role of protein kinase $C$ and reactive oxygen species. Circu- 
lation. 2003;107:1017-23;Available from: https://doi.org/10. 1161/01.cir.0000051367.92927.07.

86. Harris RE. Cyclooxygenase-2 (cox-2) and the inflammogenesis of cancer. Subcell Biochemistry. 2007;42:93-126;PMID: 17612047. Available from: https://doi.org/10.1007/1-40205688-5_4.

87. $\mathrm{Xu}$ K, Shu HK. EGFR activation results in enhanced cyclooxygenase-2 expression through p38 mitogenactivated protein kinase-dependent activation of the $\mathrm{Sp} 1 / \mathrm{Sp} 3$ transcription factors in human gliomas. Cancer Research. 2007;67:6121-9;PMID: 17616668. Available from: https://doi.org/10.1158/0008-5472.CAN-07-0141.

88. Verma S, Chandra H, Banerjee M. Cyclooxygenase 1 (COX1) expression in type 2 diabetes mellitus: a preliminary study from North India. Egypt Journal of Medicine and Human Genetics. 2016;17:41-5;Available from: https://doi.org/10.1016/ j.ejmhg.2015.07.003.

89. Guo Z, Su W, Allen S, Pang H, Daugherty A, Smart E, Gong MC. COX-2 up-regulation and vascular smooth muscle contractile hyper-reactivity in spontaneous diabetic mice. Cardiovascular Research. 2005;67:723-35;PMID: 15885672. Available from: https://doi.org/10.1016/j.cardiores.2005.04.008.

90. Szerafin T, Erdei N, Fülöp T, Pasztor ET, Edes I, Koller A, Bagi Z Increased cyclooxygenase-2 expression and prostaglandinmediated dilation in coronary arterioles of patients with diabetes mellitus. Circulation Research. 2006;99:e12-7;PMID: 16917094. Available from: https://doi.org/10.1161/01.RES. 0000241051.83067.62.

91. Redondo S, Ruiz E, Gordillo-Moscoso A, Navarro-Dorado J, Ramajo M, Rodríguez E, Reguillo F, Carnero M, Casado M, Tejerina T. Overproduction of cyclo-oxygenase-2 (COX-2) is involved in the resistance to apoptosis in vascular smooth muscle cells from diabetic patients: a link between inflammation and apoptosis. Diabetologia. 2011;54:190-9;PMID: 20957341. Available from: https://doi.org/10.1007/s00125010-1947-x.

92. Cheng H, Fan X, Moeckel GW, Harris RC. Podocyte COX-2 exacerbates diabetic nephropathy by increasing podocyte (pro) renin receptor expression. Journal of American Society of Nephrology. 2011;22:1240-51;PMID: 21737546. Available from: https://doi.org/10.1681/ASN.2010111149.

93. Cheng HF, Wang CJ, Moeckel GW, Zhang MZ, McKanna $J A$, Harris RC. Cyclooxygenase-2 inhibitor blocks expression of mediators of renal injury in a model of diabetes and hypertension. Kidney International. 2002;62:9299;PMID: 12164875. Available from: https://doi.org/10.1046/j. 1523-1755.2002.00520.x.

94. Nasrallah R, Robertson SJ, Hébert RL. Chronic coX inhibition reduces diabetes-induced hyperfiltration, proteinuria, and renal pathological markers in 36week B6-Ins2Akita mice. American Journal of Nephrology. 2009;30:346-53;PMID: 19609076. Available from: https://doi.org/10.1159/000229304.

95. Quilley J, Santos M, Pedraza P. Renal protective effect of chronic inhibition of COX-2 with SC-58236 in streptozotocindiabetic rats. American Journal of Physiology-Heart and Circulatory Physiology. 2011;300:H2316-22;PMID: 21441310. Available from: https://doi.org/10.1152/ajpheart.01259.2010.

96. Abdelrahman AM, Al Suleimani YM. Four-week administration of nimesulide, a cyclooxygenase- 2 inhibitor, improves endothelial dysfunction in the hind limb vasculature of streptozotocin-induced diabetic rats. Archives of Pharmacal Research. 2008;31:1584-9;PMID: 19099228. Available from: https://doi.org/10.1007/s12272-001-2155-5.

97. Botting RM. Inhibitors of cyclooxygenases: mechanisms, selectivity and uses. Journal of Physiology and Pharmacology. 2006;57:113-24;PMID: 17218763.

98. Bunimov N, Laneuville O. Cyclooxygenase inhibitors: in- strumental drugs to understand cardiovascular homeostasis and arterial thrombosis. Cardiovascular and Hematological Disorders-Drug Targets. 2008;8:268-77;Available from: https: //doi.org/10.2174/187152908786786250.

99. Liavonchanka A, Feussne I. Lipoxygenases: Occurrence, functions and catalysis. Journal of Plant Physiology. 2005;163:348-35;Available from: https: //doi.org/10.1016/j.jplph.2005.11.006.

100. Dobrian AD, Morris MA, Taylor-Fishwick DA, Holman TR, Imai Y, Mirmira RG, Nadler JL. Role of the 12-lipoxygenase pathway in diabetes pathogenesis and complications. Pharmacology and Therapeutics. 2019;195:100-10;Available from: https://doi.org/10.1016/j.pharmthera.2018.10.010.

101. Wei R, Enaka M, Muragaki Y. Activation of KEAP1/NRF2/P62 signaling alleviates high phosphate-induced calcification of vascular smooth muscle cells by suppressing reactive oxygen species production. Scientific Reports. 2019;9:10366;PMID: 31316111. Available from: https://doi.org/10.1038/s41598-019-46824-2.

102. Luci D, Jameson JB, Yasgar A, Diaz G, Joshi N, Kantz A, Markham K, Perry S, Kuhn N, Yeung J, Schultz L, Holinstat M, Nadler J, Taylor-Fishwick DA, Jadhav A, Simeonov A, Holman TR, Maloney DJ. Discovery of ML355, a potent and selective inhibitor of human 12-lipoxygenase. [Updated $2014 \mathrm{Sep}$ 18]. In: Probe Reports from the NIH Molecular Libraries Program [Internet]. Bethesda (MD): National Center for Biotechnology Information (US); 2010-. 2013;Available from: https: //www.ncbi.nlm.nih.gov/books/NBK259188/.

103. Adili R, Tourdot BE, Mast K, Yeung J, Freedman JC, Green A, Luci DK, Jadhav A, Simeonov A, Maloney DJ, Holman TR, Holinstat, M. First selective 12-LOX inhibitor, ML355, impairs thrombus formation and vessel occlusion in vivo with minimal effects on hemostasis highlights. Arteriosclerosis Thrombosis and Vascular Biology. 2017;37:1828-39;Available from: https://doi.org/10.1161/atvbaha.117.309868.

104. Rabbani N, Thornalley PJ. Hexokinase-2 glycolytic overload in diabetes and ischemia-reperfusion injury. Trends Endocrinology and Metabolism. 2019;30:419-31;Available from: https://doi.org/10.1016/j.tem.2019.04.011.

105. Li W, Huang C, Hsieh Y, Chen T, Cheng L, Chen C, Liu C, Chen $H$, Huang C, Lo J, Chang K. Regulatory role of hexokinase 2 in modulating head and neck tumorigenesis. Frontiers in Oncology. 2020;10:176;Available from: https://doi.org/10.3389/ fonc. 2020.00176

106. Nederlof R, Gürel-Gurevin E, Eerbeek $O$, Xie C, Deijs GS, Konkel $\mathrm{M}$, Hu J, Weber NC, Schumacher CA, Baartscheer A, Mik EG, Hollmann MW, Akar FG, Zuurbier CJ. Reducing mitochondrial bound hexokinase II mediates transition from noninjurious into injurious ischemia/reperfusion of the intact heart. Journal of Physiology and Biochemistry. 2017;73:32333;PMID: 28258543. Available from: https://doi.org/10.1007/ s13105-017-0555-3.

107. Hariton F, Xue M, Rabbani N, Fowler M, Thornalley PJ. Sulforaphane delays fibroblast senescence by curbing cellular glucose uptake, increased glycolysis, and oxidative damage. Oxidative Medicine and Cellular Longevity. 2018;2018:5642148;PMID: 30595796. Available from: https: //doi.org/10.1155/2018/5642148.

108. Irshad Z, Xue M, Ashour A, Larkin JR, Thornalley PJ, Rabbani $\mathrm{N}$. Activation of the unfolded protein response in high glucose treated endothelial cells is mediated by methylglyoxal. Scientific Reports. 2019;9:7889;PMID: 31133647. Available from: https://doi.org/10.1038/s41598-019-44358-1.

109. Sans CL, Satterwhite DJ, Stoltzman CA, Breen KT, Ayer DE. MondoA-Mlx heterodimers are candidate sensors of cellular energy status: mitochondrial localization and direct regulation of glycolysis. Molecular and Cell Biology. 2006;26:486371;PMID: 16782875. Available from: https://doi.org/10.1128/ MCB.00657-05. 